\title{
$\bigcirc$ THE USE OF ADDRESS PRONOUNS AMONG FINNISH AND FINLAND-SWEDISH STUDENTS
}

\author{
Heidi Nyblom, University of Vaasa \\ Heidi Nyblom is a PhD student in the Department of Scandinavian Languages at \\ the University of Vaasa in Finland. She has also been an in-country research assistant \\ for the project Address in some western European languages at the University of \\ Melbourne. Her research interest includes address in language contact situations.
}

\begin{abstract}
This article examines the use and choice of address pronouns among Finnish and Finland-Swedish students in various situations. The study is based on a questionnaire on address usage distributed to university students in the city of Vaasa in Finland. The aim of the study is to investigate potential differences between the use of $\mathrm{T}$ and $\mathrm{V}$ in Finnish and Finland-Swedish and to compare the results with those of a recent study on address in Sweden-Swedish. The results reveal that the FinlandSwedish students use $V$ somewhat less than the Finnish students. The Finland-Swedes also use $V$ in fewer contexts, primarily in service situations and occasionally to strangers and public authorities. The Finnish students use $V$ in the same contexts as the Finland-Swedish, but they also use $\mathrm{V}$ to older people.
\end{abstract}

\section{INTRODUCTION}

This article focuses on differences and similarities in the use and choice of address pronouns among Finnish and Finland-Swedish students. The address pronoun system in Finnish comprises sinä (less formal, T) and te (more formal, V), and in Swedish $d u$ (less formal, $\mathrm{T}$ ) and $n i$ (more formal, $\mathrm{V}$ ). There are no recent studies that compare address use in these two languages, even though there are some studies on address in Finnish (Noponen 1999; Seppänen 1989; Yli-Vakkuri 1986) and in Finland-Swedish respectively (Fremer 1998; Norrby 2004; Nyblom 2004; Saari 1995). The data on which this article is based come from a questionnaire on address usage distributed to university students in the city of Vaasa in Finland. Vaasa is the regional centre of Ostrobothnia, a province on the west coast. The majority $(52.1 \%)$ of the population in Ostrobothnia is Swedishspeaking, and Vaasa is formally recognised as a bilingual city with $25.2 \%$ Finland-Swedes. This represents a substantial percentage of Swedish speakers, when compared with national figures of $5.6 \%{ }^{1}$ 
The main aim of this study is to investigate whether there are any differences between the use of $\mathrm{T}$ and $\mathrm{V}$ in Finnish and Finland-Swedish among young people at university. In addition, it aims to compare the results regarding the Finland-Swedish students with results from an earlier study on address in Finland-Swedish and Sweden-Swedish undertaken by Norrby in 2004.

\section{ADDRESS SYSTEMS IN FINNISH AND FINLAND-SWEDISH}

It has been shown that Finnish and Swedish conversational patterns are different: according to Saari (1995), Swedes communicate in patterns of positive politeness, Finns in patterns of negative politeness. ${ }^{2}$ As far as address forms are concerned, the $\mathrm{V}$ form is more common in Finnish (Saari 1995), whereas the T form is more frequent in Swedish (Norrby 2004, 2005). However, direct T or V address tends to be avoided in Finnish, and titles, first names, surnames, third person pronouns or passive forms are used instead. These forms of indirect address are more commonly used in Finnish than in Swedish. There is recent conflicting evidence of change in the Finnish system. On the one hand, it has been reported that the use of $\mathrm{V}$ in Finnish has slightly increased overall. An orientation towards Europe and languages such as German and French, which have functioning $\mathrm{T}$ and $\mathrm{V}$ systems, has been considered to be one of the reasons for this trend (see articles in Kielikello 1999). On the other hand, studies from the late 1990s show that the use of the $\mathrm{T}$ form has increased among young people (Noponen 1999).

There are also differences between address usage in the two national varieties of Swedish, i.e. Sweden-Swedish and Finland-Swedish (Fremer 1998; Norrby 1997 and also in this issue; Saari 1995). The special case of Finland Swedish can be explained through its contact with the majority language Finnish and also with the dominant Swedish variety spoken across the Baltic. There are three main differences between the SwedenSwedish and the Finland-Swedish address systems, which will be examined in turn:

1. The negative connotations associated with $\mathrm{V}$ in Sweden-Swedish do not apply to the $\mathrm{V}$ form in Finland-Swedish.

2. The " $d u$-reform" which took place in Sweden was not a complete success in FinlandSwedish contexts.

3. Indirect address is more commonly used in Finland-Swedish.

The $\mathrm{V}$ address pronoun $n i$ has traditionally had negative connotations in Sweden because of the complicated use of titles as address forms during the 19th century and up to the middle of the 20th century. At the time $n i$ was, and still is, considered to be impolite, 
especially among elderly people (Teleman 2003, 150ff.). In Finland-Swedish this has not been the case since $n i$ has been regarded as polite (Nyblom 2004). Already in the early 20 th century it was common for students to address their professors as $n i$ (Östergren 1913). This would never have been possible in Sweden at that point of time: the correct address form would have been title and surname. The lack of these negative connotations concerning ni enables a greater range of uses of the address pronoun $\mathrm{V}$ in Finland-Swedish (Norrby 2004).

In Sweden, increased use of $d u$ during the 1950s and 1960s led to the abolition of $n i$ and titles. This is commonly known as the " $d u$-reform" (Teleman 2003, 154). The use of $d u$ spread rapidly to all levels of Swedish society, and by the end of the 1970s, $d u$ was the only address pronoun in common use in Sweden (Norrby 1997, 322). According to Fremer (cited in Winter 2004), this reform also affected Finland-Swedish, but the Finland-Swedes did not abandon the use of $n i$ because of the influence of the Finnish language. However, this mainly applies to Helsinki Swedish. In the countryside, especially in Ostrobothnia, the use of $d u$ has been more common than in Helsinki (Mara and Huldén 2000; Norrby 2004). It can be assumed that the influence from Finnish is less pronounced in Ostrobothnia, which has a Swedish-speaking majority $(52.1 \%)$ and a strong orientation towards Sweden (see 'Research site and instruments' below).

Studies by Saari (1995) and Fremer (1998) show that the use of indirect address, e.g. third-person pronouns or passive forms, is more common in Finland-Swedish than in Sweden-Swedish. This can be seen as a sign of a more formal use of address forms in Finland-Swedish.

This suggests, then, that Finland-Swedish address usage is influenced both by Finnish and by Sweden-Swedish. Finland-Swedish uses the Sweden-Swedish address forms, but their distribution differs, showing more resemblances with the Finnish address system (e.g. the use of $\mathrm{V}$ and indirect address). However, the $\mathrm{V}$ form is not as common in FinlandSwedish as it is in Finnish.

Based on the earlier studies reported above, it was hypothesised that the FinlandSwedish students would use V less than the Finnish students. In comparison to previous results from Sweden, it was further predicted that the Finland-Swedish students would use V more than the Sweden-Swedes. This leads to the following question: is the FinlandSwedish address system more influenced by Finnish or Sweden-Swedish? 


\section{RESEARCH SITE AND INSTRUMENTS}

This study is based on a questionnaire on address usage distributed to university students in Vaasa. This city was chosen as research site for three reasons. First, it is a bilingual city, where Swedish/Finnish institutionalised bilingualism can be observed and experienced in everyday life, as the inhabitants have the right to use their mother tongue in, for example, health care, service situations, and education. Second, Vaasa has very strong connections to Sweden, greatly facilitated by access to Swedish TV channels, by co-operation between organisations and companies in the two countries, and by the ferry service across the Gulf of Bothnia (from Vaasa in Finland to Umeå in Sweden). Young FinlandSwedes living in Vaasa or in the surrounding area are also very orientated towards Sweden and keep up-to-date with Swedish fashion, music, films and other contemporary trends. Third, all previous studies on address in Finland-Swedish have been carried out in Helsinki and therefore concentrate on Helsinki Swedish. The conditions in Helsinki differ from those in Vaasa; for example, Finland-Swedes make up only $6.3 \%$ of the Helsinki population, and in comparison to Vaasa Finnish has a stronger impact on everyday life in Helsinki.

The questionnaire contained 44 questions about how the informants would address parents, step-parents, grandparents and their friends, a friend's parents, their partner's parents, a younger neighbour, an older neighbour, an unknown person (in writing), salespersons, customers, public authorities, lecturers and professors, as well as superiors, at work. ${ }^{3}$ At the end of the questionnaire the informants could write down comments on their usage of address forms. The data therefore relate to reported and not actual use of address forms.

A total of 316 university students participated in the study - 162 female and 154 male students. Out of these students 172 were Finland-Swedes from Ostrobothnia, and 144 students were Finnish-speaking and came from different regions of the country. The majority of the students were 20-25 years old and were studying computer science, economics or public administration.

\section{RESULTS}

Many of the questions resulted in $100 \% \mathrm{~T}$ (for example, addressing parents, grandparents etc.). There were also a number of questions that resulted in nearly $100 \% \mathrm{~T}$ (for example, address of friend's parents, partner's parents, younger neighbour, colleagues at work). These were all questions where $\mathrm{T}$ was expected. 
Due to space restrictions, it is not possible to discuss every question. In this article I focus on questions that resulted in more than $50 \% \mathrm{~V}$, and/or questions where the Finnish and Finland-Swedish results differ. Table 1 shows the questions selected for discussion here. It also shows the distribution of address pronouns between the Finland-Swedish and the Finnish students in percentages.

\begin{tabular}{lrrrrrrrrr}
\hline \multicolumn{1}{c}{ Addressee } & \multicolumn{3}{c}{ Finland-Swedish } & \multicolumn{3}{c}{ Finnish } \\
& $\mathbf{T}$ & $\mathbf{V}$ & $\mathbf{T} / \mathbf{V}$ & $\boldsymbol{\sigma}$ & $\mathbf{T}$ & $\mathbf{V}$ & $\mathbf{T} / \mathbf{V}$ & $\boldsymbol{\varnothing}$ \\
\hline Unknown person (in writing) & $\mathbf{2 4}$ & $\mathbf{6 5}$ & 3 & 8 & 13 & $\mathbf{7 7}$ & 4 & 6 \\
\hline Unknown older person & $\mathbf{5 0}$ & $\mathbf{5 0}$ & 0 & 0 & 10 & $\mathbf{9 0}$ & 0 & 0 \\
\hline Friend of grandparents & $\mathbf{6 2}$ & 24 & 0 & 14 & 24 & $\mathbf{6 3}$ & 0 & 13 \\
\hline Public authority & 34 & $\mathbf{6 6}$ & 0 & 0 & 34 & $\mathbf{6 6}$ & 0 & 0 \\
\hline Superior at work & $\mathbf{6 9}$ & 19 & 0 & 12 & $\mathbf{6 0}$ & 12 & 0 & 28 \\
\hline Salesperson & 47 & $\mathbf{5 3}$ & 0 & 0 & $\mathbf{5 6}$ & 44 & 0 & 0 \\
\hline Client/customer & 29 & $\mathbf{5 1}$ & 3 & 17 & 9 & $\mathbf{5 6}$ & 14 & 21 \\
\hline Lecturer & $\mathbf{7 6}$ & 6 & 2 & 16 & $\mathbf{5 1}$ & 32 & 7 & 10 \\
\hline Professor & $\mathbf{6 2}$ & 12 & 1 & 25 & 33 & $\mathbf{3 8}$ & 6 & 23 \\
\hline
\end{tabular}

Table 1 Reported use of $\mathrm{T}$ and $\mathrm{V}$ in selected situations (questionnaire data) among students in Vaasa

All percentages over $50 \%$ are in bold. T/V stands for responses where the students marked both $T$ and $V$ and $\emptyset$ stands for unanswered questions.

In the rest of the paper, each of the situations in Table 1 will be discussed in more detail.

\section{ADDRESSING AN UNKNOWN PERSON (IN WRITING)}

In response to the question 'Which term of address do you use when writing an email to an unknown person?', the majority of both the Finland-Swedish $(65 \%)$ and the Finnish $(77 \%)$ informants said that they would use the $\mathrm{V}$ form. The high reported use of the $\mathrm{V}$ form is surprising, given that the Internet and emailing have in general led to more informal communicative patterns (see Severinson Eklundh 1997, 120-121).

Some of the students commented that it was somewhat more difficult to choose between $\mathrm{T}$ and $\mathrm{V}$ in writing, but that they still would choose the $\mathrm{V}$ form 'just in case' (Finland-Swedish, male), 'because it is safer' (Finland-Swedish, male) and given that 'the risk of hurting another person's feelings is minor when using the V form' (Finnish, female). Some students pointed out that the most important thing when addressing strangers is to be polite, and politeness is expressed by using V. 


\section{ADDRESSING OLDER PEOPLE}

The responses to the questions 'How do you address an unknown person who is considerably older than you?' and 'How would you address a friend of your grandparents?' show a difference between the Finnish students' and the Finland-Swedish students' choices of address pronouns. In both cases, the majority of the Finnish students chose the $\mathrm{V}$ form when addressing an older person $(90 \%)$ and a friend of their grandparents $(63 \%)$.

In contrast the Finland-Swedes chose $\mathrm{T}$ to a much greater extent. When addressing a friend of their grandparents, the majority of the Finland-Swedish students chose the $\mathrm{T}$ form $(62 \%)$, which indicates that the Finland-Swedes are somewhat more informal as regards relatives, family and family friends, even where older people are concerned. However, when addressing someone older and unknown, the variation is remarkable: $50 \%$ of the Finland-Swedish informants chose $\mathrm{T}$ and $50 \%$ chose V. This indicates that the factor of known/unknown is a stronger factor for the choice of $\mathrm{V}$ among the FinlandSwedish students than age: a stranger or an unknown person is a strong factor in favour of $\mathrm{V}$ and a friend of grandparent is not.

\section{ADDRESSING PUBLIC AUTHORITIES}

In response to the question 'How would you address the person who answers the phone when calling a public authority?', two thirds of both the Finland-Swedish (66\%) and Finnish $(66 \%)$ students chose the $\mathrm{V}$ form. However the students' comments on this question suggest a difference between the two language groups. Two of the FinlandSwedish students said that they used the $\mathrm{V}$ form in a plural sense: they did not address the person who answered the phone as an individual, but as a representative of the public authority as a whole. None of the Finnish students commented on a plural use of V. Instead, seven of the Finnish students - and three of the Finland-Swedish students claimed that they used the $\mathrm{V}$ form (i.e. in the singular sense) in official and formal situations, such as when communicating with public authorities.

Again, there is variation in the use of address pronouns among the Finland-Swedish students, which suggests that the choice of the appropriate address form is more complicated in Finland-Swedish than in Finnish (see also Norrby 2006 for a discussion on Finland Swedish in relation to Sweden Swedish). As seen above, using plural V is a way for a minority of students to avoid directly addressing their interlocutor.

\section{ADDRESSING SUPERIORS AT WORK}

From the responses to the question 'How do you address your superiors at work?', it is clear that superiors are generally addressed with T both in Finland-Swedish (69\%) and 
in Finnish $(60 \%)$. The workplace is considered to be one area in society where the ' $d u$-reform' has succeeded. However, $19 \%$ of the Finland-Swedish and $12 \%$ of the Finnish students chose $\mathrm{V}$ for this particular question. Furthermore, $12 \%$ of the Finland-Swedish and $28 \%$ of the Finnish students left the question unanswered, perhaps because they do not work.

\section{ADDRESSING SALESPERSONS}

In response to the question 'How do you address salespersons?', the majority (53\%) of the Finland-Swedish students chose the V form. Again, two of the Finland-Swedish students said that when they address salespersons they use $\mathrm{V}$ because they are referring to the whole shop, and are thus using the form in a plural sense. None of the Finnish students gave this explanation. Although Finnish-speaking colleagues have told me that it is also common to use $\mathrm{V}$ in a plural sense when addressing a salesperson in Finnish, the majority of the Finnish students (56\%) still chose the $\mathrm{T}$ form (44\% chose $\mathrm{V})$.

How to explain the choice of $\mathrm{V}$ among the Finland-Swedish students? It may be a way of getting around the problematic choice of the appropriate address form. We can also hypothesise that it is more logical to address a salesperson with $\mathrm{V}$ when enquiring about a specific item, because it is then made clear that you simply want to know whether the shop has the item for sale or not, and thus the salesperson is not viewed as personally responsible for the items in the shop.

The choice of $\mathrm{T}$ among the Finnish students shows that the usage of address forms has become less formal in Finnish. This confirms the results from a previous study by Noponen (1999) among Finnish university students in Helsinki at the end of the 1990s. Noponen showed that there had been remarkable changes in attitudes towards $\mathrm{T}$ and $\mathrm{V}$ and that the use of T had increased by $20 \%$ among this group since the end of the 1980s. However, Noponen noted that there were still situations where the majority of the students used the $\mathrm{V}$ form. These included situations such as addressing a public authority (an official employee who is at least 30 years old) on a formal matter, and when addressing a sales person who is older than 30 . In these situations, $50 \%$ of the students would use the $\mathrm{V}$ form.

\section{ADDRESSING CLIENTS OR CUSTOMERS}

From the responses to the question 'How do you address clients?', it seems that the majority of those students who responded - both Finland-Swedish and Finnish - addressed customers with the $\mathrm{V}$ form. Some of the students commented on this, saying that they always used the $\mathrm{V}$ form when addressing customers. However, there is some variation 
in the responses. $51 \%$ of the Finland-Swedish and $56 \%$ of the Finnish students chose V. $29 \%$ of the Finland-Swedish and only $9 \%$ of the Finnish students chose T, suggesting that the Finland-Swedes are somewhat less formal. Some of the students chose both $\mathrm{T}$ and V $-3 \%$ of the Finland-Swedish and $14 \%$ of the Finnish students. Some students commented that they used $\mathrm{T}$ to younger customers and $\mathrm{V}$ to older ones. $17 \%$ of the Finland-Swedish and $21 \%$ of the Finnish students left the question unanswered: we can surmise that some might prefer to avoid directly addressing customers, and others might not have a service related job or a job at all.

\section{ADDRESSING LECTURERS AND PROFESSORS}

In general professors are older than lecturers and they usually teach more advanced courses. It was therefore felt worthwhile to compare students' choices of address pronouns with each of the two groups, particularly as the majority of the informants were in their first or second year of studies at university.

In response to the question 'How do you address your lecturers?' $76 \%$ of the FinlandSwedish and $51 \%$ of the Finnish students chose to address their lecturers with T. $32 \%$ of the Finnish students and only $6 \%$ of the Finland-Swedish students chose V. The Finland-Swedes seem once again to be less formal than the Finns. A small minority of students chose both $\mathrm{T}$ and $\mathrm{V}-2 \%$ of the Finland-Swedish and $7 \%$ of the Finnish students. According to the results, the students are on very familiar terms with their lecturers. The reduced distance between students and lecturers today can be seen in the light of a general societal trend towards more informal conversational patterns.

In response to the question 'How do you address your professors?', $62 \%$ of the Finland-Swedish and $33 \%$ of the Finnish students chose to address their professors by T. $38 \%$ of the Finnish students, but only $12 \%$ of the Finland-Swedish students, chose V. The raw data show a clear difference between the two language groups. The FinlandSwedes are less formal. Again, a very small minority of the students chose both $\mathrm{T}$ and $\mathrm{V}-6 \%$ of the Finnish students and only $1 \%$ of the Finland-Swedish students. However, a number of students left the question unanswered $-25 \%$ of the Finland-Swedish and $23 \%$ of the Finnish students. This lack of response may be due to the fact that first- and second-year students have little contact with professors. Thus, the factor of familiarity might in this case be a reason for the choice of V. There might, however, also be other reasons for the choice of $\mathrm{V}$. In the last part of the questionnaire, where the students were asked to comment on the use of address forms, some of the Finnish students said that they address people in authority with V: professors would fall into this category. 
The Finland-Swedish students, however, tend to address both lecturers and professors with T. One reason for this might be that in Vaasa institutions offering education in Swedish are quite small. It is therefore easier to get to know the lecturers and professors and to be on more familiar terms with them. However, as in the case of addressing superiors at work with $\mathrm{T}$, addressing professors with $\mathrm{T}$ also indicates that the students do not see $\mathrm{T}$ use as related to status or age. This also points to an orientation towards $d u$ in general.

\section{DISCUSSION AND CONCLUSIONS}

As was seen in Table 1, the use of $\mathrm{V}$ is slightly more common in Finnish than in FinlandSwedish. More than $50 \%$ of the Finland-Swedish students report that they use the V form at least in the following four situations: when addressing unknown persons in writing, public authorities (also in a plural sense), salespersons (also in a plural sense) and customers. More than $50 \%$ of the Finnish students use the $\mathrm{V}$ form in five situations: when addressing unknown persons in writing, unknown older persons, friends of their grandparents, public authorities, and customers.

When the results from this study are compared to results from a previous study (Norrby 2004), the difference between Finnish and Finland-Swedish on one hand and Sweden-Swedish on the other hand is clear. Norrby (2004) sets out a series of situations which can trigger the use of V in Sweden-Swedish and Finland-Swedish. Her results, set out in Table 2 (marked as Sweden-Swedish 2004 and Finland-Swedish 2004), are based on two focus group discussions (with around 15 participants in each) held in Gothenburg and Vaasa in the autumn of 2003. The age of the participants ranged from 20 to 67 (Norrby 2004). In Table 2, a 'yes' indicates that the $\mathrm{V}$ form is used by $50 \%$ or more of the informants and a '(yes)' indicates that the $\mathrm{V}$ form is used by less than $50 \%$.

As Table 2 shows, when we compare Norrby's results (marked with 2004) and the Finland-Swedish and Finnish results in this present study, there are slight differences between the two sets of situations as far as Finland-Swedish is concerned. These can be accounted for by the fact that the present study only includes students, i.e. young people, whereas Norrby's study included people of different ages. Bearing this in mind, it is worth noting that, when comparing the results on Sweden-Swedish, Finland-Swedish and Finnish in Table 2, the address system in Finland-Swedish bears more likeness to the Finnish address system than to that of Sweden-Swedish. This supports the studies on Helsinki Swedish undertaken by Fremer (1998) and Saari (1995), where they state that 
the Finland-Swedish address system shows more similarities to the Finnish address system than to the Sweden-Swedish.

\begin{tabular}{lcccc}
\hline & $\begin{array}{c}\text { Sweden- } \\
\text { Swedish } \\
\text { (2004) }\end{array}$ & $\begin{array}{c}\text { Finland- } \\
\text { Swedish }\end{array}$ & $\begin{array}{c}\text { Finland- } \\
\text { Swedish }\end{array}$ & Finnish \\
& $\mathbf{( 2 0 0 4 )}$ & (2006) & (2006) \\
\hline Older people are addressed with V & (yes) & yes & (yes) & yes \\
\hline Young people use V & no & (yes) & yes & yes \\
\hline $\begin{array}{l}\text { Unknown people and business } \\
\text { contacts, such as customers and } \\
\text { patients, are addressed with V }\end{array}$ & (yes) & yes & yes & yes \\
\hline $\begin{array}{l}\text { People with higher status are } \\
\text { addressed with V }\end{array}$ & no & yes & (yes) & yes \\
\hline
\end{tabular}

Table 2 Situations which can trigger the use of V: general tendencies

The results of the present study indicate that Finland-Swedish students use $\mathrm{V}$ to nearly the same degree as Finnish students. They do, however, use V in fewer contexts, primarily in service situations and occasionally to strangers and public authorities when they wish to keep a distance. An obvious conclusion would be that the usage of address pronouns among young Finland-Swedish students in Ostrobothnia is influenced by Finnish address patterns. But does this mean that any influence from Sweden-Swedish, where the use of $\mathrm{T}$ is widespread, can be discounted? In what follows, an alternative interpretation is proposed. In the 1980s, Mårtensson (1986), in an article on the revived and new functionally different use of $n i$, found that young Swedes had begun to use $n i$ again. Being unaware of its negative connotations for some speakers, they used it to be polite and to show respect towards the elderly. Even if more recent studies (Norrby 1997; Norrby and Håkansson 2003) show that the use of $n i$ is not as common as Mårtensson's study indicated, discussions about the new $n i$ have been seen and heard in Swedish media. The discussions have revolved around a new $n i$ used by young people who wish to keep a polite distance in service situations and when addressing older people. News about the new $n i$ has also reached the Swedish-speaking parts of Finland through the media, ${ }^{4}$ and it might be assumed that this would have an impact on the use of address forms among young Finland-Swedes in Ostrobothnia. 


\section{ENDNOTES}

For an outline of the Swedish-speaking areas in Finland see Svenska Finlands Folkting (2003).

The theory of positive politeness and negative politeness was introduced by Brown and Levinson in 1978. The theory is based on the need to avoid face-threatening acts. This can be done in two ways, either by strategies of positive politeness (direct address) or by strategies of negative politeness (indirect address) (Brown and Levinson 1987 [1978]). Even though this theory has received some criticism for being too one-sided (see the Journal of Pragmatics vol. 14, 2, 1990), Saari $(1995,82)$ argues that it is of relevance concerning Scandinavian languages.

The questionnaire draws on the questionnaire and interview used in the Australian-based project Address in some western European languages (2004; see also Clyne et al. 2004).

In 2003, the Sweden-Swedish television station SVT broadcast a programme about the Swedish language called Värsta språket. The same programme was broadcast on the FinlandSwedish televison station FST in 2004. In 2005, some of the Finland-Swedish newspapers (e.g. Österbottningen 13-3-2005) published an article on address in Swedish, Snart kanske $d u$ säger ni igen ('Soon you ( $\mathrm{T}$ ) might use the $\mathrm{V}$ form again'). Both the television programme and the newspaper article discussed the use of $n i$ (and the new ni) in Swedish, but they did not mention that it concerned address in Sweden-Swedish. This might have led to some false interpretations concerning a new $n i$ in Finland-Swedish.

\section{REFERENCES}

Address in some western European languages. 2004. Schoool of Languages, The University of Melbourne. Cited April 8, 2004. Formerly available from http://www.rumaccc.unimelb.edu.au/Address/Address.html.

Brown, P.; Levinson, S.C. 1987. Politeness: Some universals in language usage. Cambridge: Cambridge University Press.

Clyne, M.; Kretzenbacher, H.L.; Norrby, C.; Warren, J. 2004. 'Address in some western European languages'. In Proceedings of the 2003 Conference of the Australian Linguistic Society, edited by Moskovsky, C. Cited April 8, 2004. Formerly available from http://www.newcastle.edu.au/school/lang-media/news/als2003/proceedings.html.

Fremer, M. 1998. 'Tilltal och omtal i samtal'. Språkbruk 2: 10-17.

Journal of Pragmatics 1990, Vol. 14 No. 2.

Kielikello. 1999. Vol. 2.

Mara, J.; Huldén, L. 2000. 'Långväga främmande tar man i hand när man hälsar’. Hälsningsvanor, tilltal och omtal i Svenskfinland under 1900-talet. Helsingfors: Svenska litteratursällskapet i Finland.

Mårtensson, E. 1986. 'Det nya niandet'. Nordlund 10: 35-79. 
Noponen, A.-L. 1999. 'Sinä vai te?' Kielikello 2. Cited January 12, 2004. Formerly available from http://www.kielikello.fi/arkisto/2_99/sina.html.

Norrby, C. 1997. 'Kandidat Svensson, du eller ni - om utvecklingen av tilltalsskicket i svenskan'. In Svenska som andraspråk och andra språk. Festskrift till Gunnar Tingbjörn, edited by Andersson, A.-B.; Enström, I.; Källström, R.; Nauclér K. Gothenburg: Institutionen för Svenska språket, Göteborgs Universitet.

Norrby, C. 2004. 'Unga och gamla vill inte nia'. Språkvård 4: 26-34.

Norrby, C. 2005. 'Du, ni, titel eller förnamn?’ Språkbruk 2: 5-10.

Norrby, C. 2006. 'Variation in Swedish address practices'. Australian Review of Applied Linguistics 29 (2): 18.1-18.15. DOI: 10.2104/aral0618.

Norrby, C.; Håkansson, G. 2003. 'Kan jag hjälpa dig med något? Om tilltal i en servicesituation’. Språk och stil 13: 5-34.

Nyblom, H. 2004. 'Dua, nia eller tiga? Tilltalsskicket bland finlandssvenska studerande i Vasa'. Unpublished paper given at the International Conference on Language, Politeness and Gender CLPG-2004. Helsinki, September 2.

Östergren, O. 1913. 'Möjligt och omöjligt i den språkliga utvecklingen'. Språk och stil 13: 203-212.

Saari, M. 1995. “'Jo, nu kunde vi festa nog”. Synpunkter på svenskt språkbruk i Sverige och Finland’. Folkmålsstudier 36: 75-108.

Seppänen, E.-L. 1989. 'Henkilöön viittaaminen puhetilanteessa'. In Kieli 4. Suomalaisen keskustelun keinoja I, edited by Hakulinen, A. Helsinki: Helsingin yliopiston suomen kielen laitos.

Severinson Eklundh, K. 1997. 'Samtalsmönster i elektroniska nätverk'. In Svenskan i IT-sambället, edited by Josephson, O. Uppsala: Hallgren \& Fallgren.

Svenska Finlands Folkting 2003. Språkfördelningen i Svenskfinland - befolkning enligt språk $i$ svenska och tvåspråkiga kommuner i Finland 31.12.2002. Cited June 6, 2005. Available from http://www.folktinget.fi/publikationer.html.

Teleman, U. 2003. Tradis och funkis. Svensk språkvård och språkpolitik efter 1800. Stockholm: Norstedts Ordbok.

Winter, J. 2004. 'Svensk du-reform i gungning. Slog aldrig igenom i Finland'. Vasabladet 11.1.

Yli-Vakkuri, V. 1986. Suomen kieliopillisten muotojen toissijainen käyttö. Turku: Turun yliopiston suomalaisen ja yleisen kielitieteen laitoksen julkaisuja.

Cite this article as: Nyblom, Heidi. 2006. 'The use of address pronouns among Finnish and FinlandSwedish students'. Australian Review of Applied Linguistics 29 (2): pp. 19.1-19.12. DOI:

10.2104/aral0619. 